\title{
Stowers Institute to open
}

Supported by a $\$ 515$ million endowment, the Stowers Institute for Medical Research will soon begin scientific research at its $\$ 200$ million headquarters currently under construction in Kansas City. The first phase of the construction project will be completed in November, when four independent scientists, including scientific director Robert Krumlauf, will move into their laboratories. "Eventually the Institute will have about 60 functioning research laboratories," says Laurie Wimberly, assistant director of public relations. The ambitious plan is to start with eight to ten laboratories in the first year and add between one to three each year thereafter.

The fortune that Kansas City native James E. Stowers amassed as founder of American Century Companies, a family of mutual funds, is making the launch possible. Eventually, Stowers and his wife will leave their entire estate, valued at around $\$ 1.3$ billion, to the Institute, which "intends to shape the practice of medicine through basic research that paves the way for more effective ways to prevent and cure disease," says Wimberly. The endowment is expected to grow to many billions of dolIars and make the Stowers Institute one of the richest privately funded scientific research programs in the world.

Scientific director Robert Krumlauf left

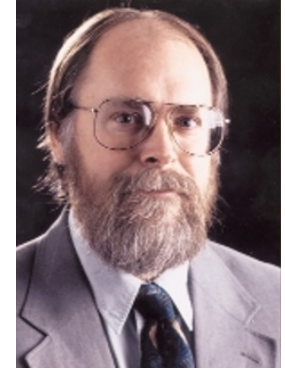

Robert Krumlauf his post as head of the Division of Developmental eurobiology at the UK's prestigious National Institute for Medical Research in Mill Hill, London, because he says he "was captured by the goal and focus of the Institute." Leanne Wiedemann, Krumlauf's wife and deputy director of the Leukaemia Research Fund Center, Chester Beatty Laboratories in London, will also join the Institute.

Krumlauf, who is renowned for his work in mouse developmental genetics, told Nature Medicine that “ $M r$. Stowers as a unique kind of philantropist, who carries with him a long-term view of invest- ing." This long-term view is what enabled Mr. Stowers to recognize the value of integrating work on fundamental biology questions with state of the art technologies. Krumlauf sees one of the goals of the Institute to put basic research into the hands of those who have the expertise and resources to translate it into medical discoveries.

Joining Krumlauf in this task will be William Neaves, former executive vice president for academic affairs at the University of Texas, Southwestern Medical Center at Dallas, who has been appointed as president and CEO of the Stowers Institute, and Nelson Pleau, Stower's chief administrator. To help guide the research focus of the Institute and steer the selection of principal investigators, the Stower's Institute has a appointed several eminent biomedical scientists to its Scientific Advisory Board, for example, Doug Melton, Howard Hughes M edical Institute investigator and chairman of the department of molecular and cellular biology at Harvard University, is the advisory board chairman.

Laura Bonetta, Bethesda

\section{AIDS defined as unique military threat}

The United Nations Security Council has adopted a resolution calling for education and condom-distribution programs to reduce HIV infection rates among UN peacekeeping troops. Although the resolution addresses a relatively tiny segment of the worldwide AIDS pandemic, it represents a major symbolic step for the security council, which had never before made a disease the focus of a resolution. The move comes on the heels of a White House announcement classifying AIDS as a threat to US national security (Nature Med 6, 117, 2000), a move expected to draw increased attention-and funding - to research on the disease. The resolution was initiated by Richard Holbrooke, US ambassador to the United Nations, who began to express concern about AIDS among peacekeeping troops in 1992. The issue remained dormant until Holbrooke visited Africa Iate last year. Mary Ellen Glynn, a staffer who accompanied the ambassador on that trip, says that "the rates of [HIV] in- fection were much higher for UN peacekeepers than for the general population." The troops appear to contract the disease primarily from local prostitutes in the areas where they are stationed.

Although the final version of the resolution was adopted unanimously, there were signs of dissent. Diplomats from countries that contribute troops for peacekeeping reportedly complained that the US, which does not have UN combat troops, was imposing conditions on other nations' citizens. Yusef Juwayeyi, Malawi's ambassador to the UN, reportedly objected to the resolution's statement that the epidemic was "exacerbated by conditions of violence and instability." Malawi is not a war zone, but the prevalence of HIV in the country's military personnel now approaches $50 \%$, one of the highest infection rates in Africa. The original resolution also contained a line which would have kept AIDS on the council's agenda for future meetings, but this was deleted by Russia and will not be discussed again by the council until the complex process of putting it back on the agenda is achieved.

To many public health experts and researchers, it might seem intuitive to increase the emphasis on malaria and tuberculosis control as well as AIDS control, so it would make scientific sense to classify these diseases as security issues also. Neal Nathanson, former director of the NIH Office of AIDS Research agrees with that assessment in principle, but points out that the skyrocketing trend in AIDS appears to have driven the new perception among policymakers and argues against trying to classify other diseases the same way. "If you keep extrapolating the AIDS situation you're really talking about something which is truly astronomical in its consequences, which could cause total social collapse, and I don't think that's true with malaria and TB," Nathanson told Nature Medicine, adding, "I think you lose credibility if you get too strident and try to put everything into the same category."

Alan Dove, Philadelphia 